\title{
Aestuariimicrobium kwangyangense gen. nov., sp. nov., an LL-diaminopimelic acid-containing bacterium isolated from tidal flat sediment
}

Correspondence
Jung-Hoon Yoon
jhyoon@kribb.re.kr

\author{
Seo-Youn Jung, Hee-Sik Kim, Jae Jun Song, Seung-Goo Lee, \\ Tae-Kwang Oh and Jung-Hoon Yoon
} Korea Research Institute of Bioscience and Biotechnology (KRIBB), PO Box 115, Yusong, Taejon,
South Korea
Many novel bacterial taxa have been isolated from a variety of tidal flats on the south and west coasts of the Korean peninsula (Jung et al., 2005, 2006a; Kim et al., 2005; Yoon et al., 2005; Lim et al., 2006). In recent years, in an attempt to investigate the microbial community of oil-contaminated tidal flat sediment in Kwangyang, Korea, many bacterial strains have been isolated and characterized taxonomically (Jung et al., 2006b). Four of these strains, designated $\mathrm{R} 27^{\mathrm{T}}$, R44, R45 and R47, which contain LLdiaminopimelic acid in the cell-wall peptidoglycan, are the subject of this study. Comparative $16 \mathrm{~S}$ rRNA gene sequence analysis indicated that the four strains are phylogenetically closely related to the family Propionibacteriaceae. Accordingly, the aim of the present work was to determine the exact taxonomic positions of strains $\mathrm{R} 27^{\mathrm{T}}$, R44, R45 and R47 using a polyphasic approach that included phenotypic properties, detailed phylogenetic analysis based on 16S rRNA gene sequences, and genetic relatedness.

The GenBank/EMBL/DDBJ accession numbers for the $16 \mathrm{~S}$ rRNA gene sequences of strains R27 ${ }^{\top}, \mathrm{R} 44, \mathrm{R} 45$ and R47 are D0830982D0830985, respectively.

A table detailing the cellular fatty acid contents of strains $R 27^{\top}, \mathrm{R} 44$, R45 and R47 is available with the online version of this paper.
Oil-contaminated tidal flat sediment collected from Kwangyang, Korea, was used as the source for the isolation of bacterial strains. Sediment samples (each $0.5 \mathrm{mg}$ ) were inoculated in $100 \mathrm{ml}$ Bushnell-Haas broth (Difco) that contained $2 \%(\mathrm{w} / \mathrm{v})$ diesel oil. Cultures were incubated at $30{ }^{\circ} \mathrm{C}$ on a horizontal shaker at 150 r.p.m. Strains $\mathrm{R} 27^{\mathrm{T}}$, $\mathrm{R} 44, \mathrm{R} 45$ and R47 were isolated from an enrichment culture with diesel oil-degradation activity by means of dilution plating on R2A agar (Difco). To investigate their morphological, physiological and biochemical characteristics, the four novel strains were routinely cultivated on $\mathrm{R} 2 \mathrm{~A}$ agar at $30{ }^{\circ} \mathrm{C}$. Growth at various temperatures from 4 to $50{ }^{\circ} \mathrm{C}$ was measured on $\mathrm{R} 2 \mathrm{~A}$ agar. The $\mathrm{pH}$ range for growth was determined in R2A broth [prepared according to the formula of the Difco medium without agar and supplemented with $2 \%(\mathrm{v} / \mathrm{v})$ Hutner's mineral base (Cohen-Bazire et al., 1957) and $0.1 \%(\mathrm{v} / \mathrm{v})$ trace element solution (Drews, 1983)] which was adjusted to various $\mathrm{pH}$ values ( $\mathrm{pH} 4.5-10.5$ at intervals of $0.5 \mathrm{pH}$ units). Growth under anaerobic conditions was determined after incubation in an anaerobic chamber on R2A agar and on R2A agar supplemented with nitrate, both of which had been prepared anaerobically using nitrogen. Cell morphology and flagellation were examined by light microscopy (E600; Nikon) and transmission electron microscopy (TEM) by 
using cells grown on R2A agar. The Gram reaction was determined by using the bioMérieux Gram stain kit according to the manufacturer's instructions. Catalase and oxidase activities and hydrolysis of casein, starch, hypoxanthine, xanthine, tyrosine and Tweens 20, 40, 60 and 80 were determined as described by Cowan \& Steel (1965). Hydrolysis of aesculin and urea and nitrate reduction were studied as described by Lanyi (1987). Acid production from carbohydrates was determined according to the method described by Leifson (1963). Utilization of various substrates for growth was assessed according to Yurkov et al. (1994). The API ZYM system (bioMérieux) was used to determine enzyme activity. Susceptibility to antibiotics was tested on R2A agar plates using discs containing the following concentrations of antibiotic: $10 \mu \mathrm{g}$ ampicillin; $100 \mu \mathrm{g}$ carbenicillin; $30 \mu \mathrm{g}$ cephalothin; $100 \mu \mathrm{g}$ chloramphenicol; $30 \mu \mathrm{g}$ gentamicin; $15 \mu \mathrm{g}$ lincomycin; $30 \mu \mathrm{g}$ kanamycin; $30 \mu \mathrm{g}$ neomycin; $5 \mu \mathrm{g}$ novobiocin; $15 \mu$ g oleandomycin; $20 \mathrm{U}$ penicillin $\mathrm{G} ; 100 \mathrm{U}$ polymyxin $\mathrm{B} ; 50 \mu \mathrm{g}$ streptomycin and $30 \mu \mathrm{g}$ tetracycline.

Strains R27 ${ }^{\mathrm{T}}$, R44, R45 and R47 were cultivated for 3 days in R2A broth prepared according to the formula of the Difco medium without agar and supplemented with $2 \%$ (v/v) Hutner's mineral base (Cohen-Bazire et al., 1957) and $0.1 \%$ trace element solution (Drews, 1983 ) at $30{ }^{\circ} \mathrm{C}$ to obtain the cell biomass required for DNA extraction and for isoprenoid quinone and cell-wall analyses. Isoprenoid quinones were analysed as described previously (Komagata
\& Suzuki, 1987) using reverse-phase HPLC. The isomer type of the diamino acid of the cell wall was analysed according to the method of Komagata \& Suzuki (1987). For fatty acid methyl ester analysis, cell mass of strains $\mathrm{R} 27^{\mathrm{T}}, \mathrm{R} 44, \mathrm{R} 45$ and $\mathrm{R} 47$ was harvested from R2A agar plates after cultivation for 3 days at $30{ }^{\circ} \mathrm{C}$. Fatty acid methyl esters were extracted and prepared according to the standard protocol of the MIDI/Hewlett Packard Microbial Identification System (Sasser, 1990). Chromosomal DNA was extracted and purified by the procedure described previously (Yoon et al., 1996). The DNA G + C content was determined using the method of Tamaoka \& Komagata (1984) with a modification in which DNA was hydrolysed and the resultant nucleotides were analysed by reversephase HPLC. Amplification of the 16S rRNA gene was performed according to the method described previously using two universal primers (Yoon et al., 1998). Sequencing of the amplified 16S rRNA gene and phylogenetic analysis were performed according to Yoon et al. (2003). DNA-DNA reassociation was determined by the microplate hybridization method (Ezaki et al., 1989) using photobiotin-labelled DNA probes.

Morphological, cultural, physiological and biochemical characteristics of strains $\mathrm{R} 27^{\mathrm{T}}$, R44, R45 and R47 are given in the genus and species descriptions (see later) or are shown in Table 1, together with those of some phylogenetically related genera. The four novel strains were identical in all of the morphological, cultural, physiological and

Table 1. Differential characteristics of Aestuariimicrobium kwangyangense gen. nov., sp. nov. and phylogenetically related LL-diaminopimelic acid peptidoglycan-containing genera

Taxa: 1, Aestuariimicrobium kwangyangense; 2, Propionibacterium propionicum (data from Maszenan et al., 1999; Bae et al., 2006); 3, Propioniferax (Yokota et al., 1994); 4, Luteococcus (Tamura et al., 1994; Collins et al., 2000, 2003); 5, Tessaracoccus (Maszenan et al., 1999). All species are Grampositive and non-motile. +, Positive; -, negative; v, variable reaction; ND, not determined.

\begin{tabular}{|c|c|c|c|c|c|}
\hline Characteristic & 1 & 2 & 3 & 4 & 5 \\
\hline Origin & Tidal flat & $\begin{array}{l}\text { Human oral cavity and } \\
\text { cervicovaginal secretion }\end{array}$ & Human epidermis & $\begin{array}{c}\text { Soil or human clinical } \\
\text { specimen }\end{array}$ & Activated sludge \\
\hline Cell morphology & $\begin{array}{l}\text { Short rods or } \\
\text { cocci }\end{array}$ & Pleomorphic rods & Pleomorphic rods & $\begin{array}{l}\text { Cocci or pleomorphic } \\
\text { rods }\end{array}$ & Cocci \\
\hline $\begin{array}{l}\text { Optimal temperature for growth } \\
\left({ }^{\circ} \mathrm{C}\right)\end{array}$ & 30 & $35-37$ & 37 & $26-28^{*}$ & 25 \\
\hline Optimal $\mathrm{pH}$ range for growth & $7.5-8.5$ & $\mathrm{ND}$ & 7.0 & ND & 7.5 \\
\hline Catalase & + & - & + & + & + \\
\hline Oxidase & - & $\mathrm{ND}$ & + & + & - \\
\hline Nitrate reduction & + & + & + & $\mathrm{V}$ & + \\
\hline DNA G $+C$ content $(\mathrm{mol} \%)$ & $68.8-69.2$ & $63-65$ & $59-63$ & $64-67$ & 74 \\
\hline
\end{tabular}

${ }^{\star}$ Data for Luteococcus japonicus are from Tamura et al. (1994). 
biochemical characteristics tested in this study, except with regard to the utilization of trehalose, benzoate and pyruvate and in the activities of naphthol-AS-BI-phosphohydrolase and $\beta$-glucuronidase. The almost complete $16 \mathrm{~S}$ rRNA gene sequences of the four strains determined in this study were identical and comprised 1472 nucleotides. Phylogenetic analysis based on 16S rRNA gene sequences showed that strains $\mathrm{R} 27^{\mathrm{T}}$, R44, R45 and R47 formed an independent lineage of descent within the family Propionibacteriaceae of the suborder Propionibacterineae (Fig. 1). In the phylogenetic tree based on the neighbourjoining algorithm, the four novel strains joined the clade comprising the genera Propionibacterium, Tessaracoccus, Brooklawnia, Propionimicrobium and Luteococcus (Fig. 1). Strains R27 ${ }^{\mathrm{T}}, \mathrm{R} 44, \mathrm{R} 45$ and R47 exhibited 16S rRNA gene sequence similarity values of less than $94.5 \%$ with respect to other species used in the phylogenetic analysis (Fig. 1). The 16S rRNA gene sequence similarity values between the four novel strains and phylogenetically related genera were as follows: Propionibacterium (93.3-90.0\%), Tessaracoccus (93.3\%), Brooklawnia (94.1\%), Propionimicrobium (92.0\%), Luteococcus (94.0-94.5\%) and Propioniferax $(92.4 \%)$. Strains $\mathrm{R} 27^{\mathrm{T}}$, R44, R45 and R47 exhibited a mean level of DNA-DNA relatedness of $91.2-97.3 \%$ when their DNA was used individually as labelled DNA probes, indicating that the four novel strains are members of the same genomic species (Wayne et al., 1987). In view of the combined phenotypic, phylogenetic and genetic similarities, strains $\mathrm{R} 27^{\mathrm{T}}, \mathrm{R} 44, \mathrm{R} 45$ and $\mathrm{R} 47$ are considered to represent members of the same species.

Strains R27 $7^{\mathrm{T}}$, R44, R45 and R47 contained LL-diaminopimelic acid as the diagnostic diamino acid in the cell-wall peptidoglycan which is characteristic of wall chemotype I sensu Lechevalier \& Lechevalier (1970). The four strains contained a tetrahydrogenated menaquinone with nine isoprene units [MK-9 $\left(\mathrm{H}_{4}\right)$ ] as the predominant isoprenoid quinone. The predominant menaquinone type [MK-9 $\left.\left(\mathrm{H}_{4}\right)\right]$ of the four novel strains was the same as that of members of the family Propionibacteriaceae (Tamura et al., 1994; Yokota et al., 1994; Nakamura et al., 1995; Stackebrandt et al., 2002; Collins et al., 2003; Bae et al., 2006). The cellular fatty acid profiles of strains R27 ${ }^{\mathrm{T}}$, R44, R45 and R47 are shown in Supplementary Table S1 (available with the online version of this paper). The major component was anteiso- $\mathrm{C}_{15: 0}(46.4-67.9 \%)$. Strain R47 was slightly different from the three other strains in the proportions of anteiso- $\mathrm{C}_{15: 0}$ and $\mathrm{C}_{16: 0}$ (see Supplementary Table $\mathrm{S} 1$ ). The DNA G $+\mathrm{C}$ contents of strains $\mathrm{R} 27^{\mathrm{T}}, \mathrm{R} 44, \mathrm{R} 45$ and $\mathrm{R} 47$ were $68.8,69.1,69.0$ and $69.2 \mathrm{~mol} \%$, respectively.

Strains R27 ${ }^{\mathrm{T}}$, R44, R45 and R47 could be clearly distinguished from other members of the family Propionibacteriaceae by differences in chemotaxonomic properties (Pitcher \& Collins, 1991; Yokota et al., 1994; Maszenan et al., 1999; Stackebrandt et al., 2002; Collins et al., 2003; Bae et al., 2006). The genus Tessaracoccus contains MK- $9\left(\mathrm{H}_{4}\right)$ and $\mathrm{MK}-7\left(\mathrm{H}_{4}\right)$ as the predominant menaquinones (Maszenan et al., 1999). Strains R27 ${ }^{\mathrm{T}}, \mathrm{R} 44, \mathrm{R} 45$ and R47 differ from the genera Propionimicrobium and Brooklawnia and Propionibacterium freudenreichii which contain lysine or meso-diaminopimelic acid as the diamino acid in position 3 of the peptidoglycan (Table 1). The fatty acid profiles, particularly major fatty acids, distinguish the four novel strains from some phylogenetically related genera, although there may be differences in the proportions of some fatty acids, probably due to differences in cultivation conditions and extraction procedures (Table 1). In particular, strains $\mathrm{R} 27^{\mathrm{T}}$, R44, R45 and R47 are clearly distinguished from the genus Luteococcus by differences in major fatty acids (Table 1). The novel four strains contain anteiso- $\mathrm{C}_{15: 0}$ as the major fatty acid, whereas members of the genus Luteococcus synthesize predominantly monounsaturated fatty acids, including $\mathrm{C}_{17: 1}, \mathrm{C}_{16: 1}, \mathrm{C}_{15: 1}$ or $\mathrm{C}_{18: 1}$ (Tamura et al., 1994; Collins et al., 2000, 2003; Supplementary Table S1). Low 16S rRNA gene sequence similarity values between the four novel strains and other members of the family Propionibacteriaceae, together with differential phenotypic properties, suggest that strains $\mathrm{R} 27^{\mathrm{T}}, \mathrm{R} 44, \mathrm{R} 45$ and $\mathrm{R} 47$ constitute a novel genus and species within the family Propionibacteriaceae, for which the name Aestuariimicrobium kwangyangense gen. nov., sp. nov. is proposed.

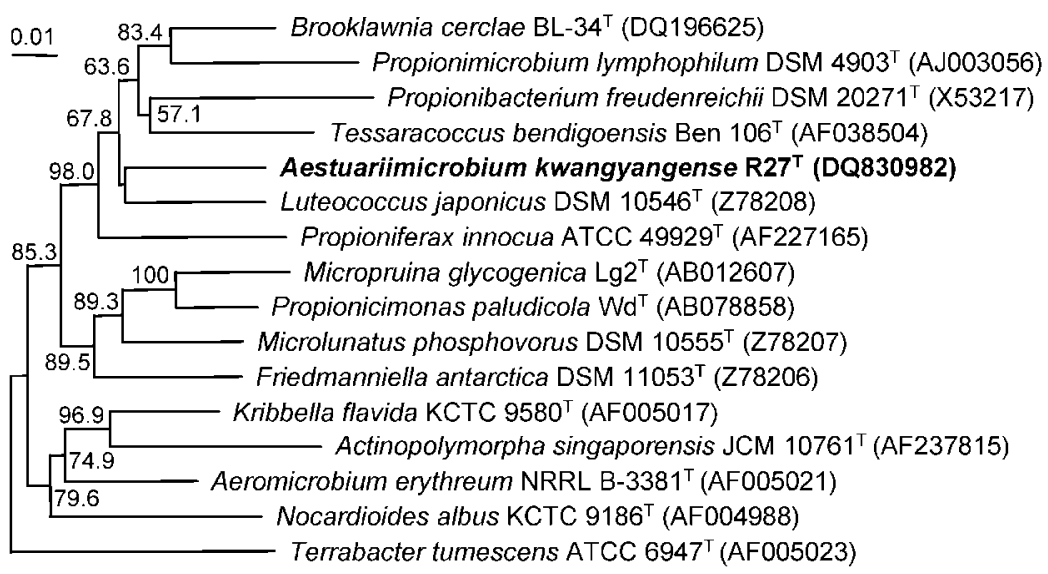

Fig. 1. Neighbour-joining tree showing the phylogenetic positions of Aestuariimicrobium kwangyangense gen. nov., sp. nov. $\mathrm{R} 27^{\top}$ and other related taxa based on 16S rRNA gene sequences. Only bootstrap values (expressed as percentages of 1000 replications) of greater than $50 \%$ are shown at the branching points. Terrabacter tumescens ATCC $6947^{\top}$ (GenBank accession number, AF005023) was used as an outgroup. Bar, 0.01 substitutions per nucleotide position. 


\section{Description of Aestuariimicrobium gen. nov.}

Aestuariimicrobium (Aes.tu.a.ri.i.mi.cro'bi.u.m. L. n. aestuarium part of the sea coast which, during the flood-tide, is overflowed, but at ebb-tide is left covered with mud or slime, a tidal flat; N.L. n. microbium microbe; N.L. neut. n. Aestuariimicrobium a microbe isolated from tidal flat).

Cells are Gram-positive, non-flagellated, short rods or cocci $(0.6-1.2 \times 1.2-2.0 \mu \mathrm{m})$. The predominant menaquinone is MK-9 $\left(\mathrm{H}_{4}\right)$. The cell-wall peptidoglycan contains LL-diaminopimelic acid. The major cellular fatty acid $\left(>10 \%\right.$ total fatty acids) is anteiso- $\mathrm{C}_{15: 0}$. The DNA $\mathrm{G}+\mathrm{C}$ content is $68.8-69.2 \mathrm{~mol} \%$. Phylogenetically, the genus Aestuariimicrobium is a member of the family Propionibacteriaceae within the suborder Propionibacterineae of the order Actinomycetales. The type species is Aestuariimicrobium kwangyangense.

\section{Description of Aestuariimicrobium kwangyangense sp. nov.}

Aestuariimicrobium kwangyangense (kwang.yang.en'se. N.L. neut. adj. kwangyangense pertaining to Kwangyang, Korea, from where the type strain was isolated).

Exhibits the following properties in addition to those given in the genus description. Colonies on R2A agar are circular, convex, smooth, yellow and $0.8-1.0 \mathrm{~mm}$ in diameter after 3 days incubation at $30{ }^{\circ} \mathrm{C}$. Growth does not occur under anaerobic conditions on R2A agar or on R2A agar supplemented with nitrate. Catalase-positive, oxidasenegative and urease-negative. Growth occurs at 4 and $40{ }^{\circ} \mathrm{C}$ with an optimum temperature of $30^{\circ} \mathrm{C}$. Optimal pH for growth is 7.5-8.5. Aesculin, casein and Tweens 20, 40, 60 and 80 are hydrolysed, but starch, hypoxanthine, xanthine and tyrosine are not. Nitrate is reduced to nitrite. D-Glucose, D-fructose, D-galactose, D-cellobiose, D-mannose, D-xylose, sucrose, maltose and salicin are utilized as sole carbon and energy sources, but L-arabinose, acetate, citrate, succinate, L-malate, formate and L-glutamate are not utilized. Utilization of trehalose (only strain R47 is negative) and benzoate and pyruvate (only strain R44 is positive) are variable. Acid is produced from D-sorbitol, Dxylose, D-fructose, melibiose, L-arabinose, D-melezitose, Dglucose, D-galactose, L-rhamnose, D-mannose, D-cellobiose, lactose, sucrose, maltose, trehalose and D-raffinose, but not from myo-inositol or D-mannitol. Susceptible to penicillin G, chloramphenicol, ampicillin, cephalothin, novobiocin, tetracycline and carbenicillin, but not to polymyxin B, streptomycin, gentamicin, kanamycin, lincomycin, oleandomycin or neomycin. Using the API ZYM system (bioMérieux), esterase (C4), esterase lipase (C8), leucine arylamidase, acid phosphatase, $\alpha$-galactosidase, $\beta$-galactosidase, $\alpha$-glucosidase and $\beta$-glucosidase are present, but alkaline phosphatase, lipase (C14), valine arylamidase, cystine arylamidase, trypsin, $\alpha$-chymotrypsin, $N$-acetyl$\beta$-glucosaminidase, $\alpha$-mannosidase and $\alpha$-fucosidase are absent. Naphthol-AS-BI-phosphohydrolase and $\beta$-glucuronidase activities (only type strain is negative) are variable.

The type strain, R27 $7^{\mathrm{T}}\left(=\right.$ KCTC $19182^{\mathrm{T}}=\mathrm{JCM} 14204^{\mathrm{T}}$ ), was isolated from oil-contaminated tidal flat sediment of Kwangyang, Korea.

\section{Acknowledgements}

This work was supported by the Eco-technopia 21 project of the Ministry of Environment and the 21C Frontier Program of Microbial Genomics and Applications (grant MG05-0401-2-0) from the Ministry of Science and Technology (MOST) of the Republic of Korea.

\section{References}

Bae, H. S., Moe, W. M., Yan, J., Tiago, I., Da Costa, M. S. \& Rainey, F. A. (2006). Brooklawnia cerclae gen. nov., sp. nov., a propionate-forming bacterium isolated from chlorosolvent-contaminated groundwater. Int J Syst Evol Microbiol 56, 1977-1983.

Cohen-Bazire, G., Sistrom, W. R. \& Stanier, R. Y. (1957). Kinetic studies of pigment synthesis by nonsulfur purple bacteria. J Cell Comp Physiol 49, 25-68.

Collins, M. D., Lawson, P. A., Nikolaitchouk, N. \& Falsen, E. (2000). Luteococcus peritonei sp. nov., isolated from the human peritoneum. Int J Syst Evol Microbiol 50, 179-181.

Collins, M. D., Hutson, R. A., Nikolaitchouk, N., Nyberg, A. \& Falsen, E. (2003). Luteococcus sanguinis sp. nov., isolated from human blood. Int J Syst Evol Microbiol 53, 1889-1891.

Cowan, S. T. \& Steel, K. J. (1965). Manual for the Identification of Medical Bacteria. London: Cambridge University Press.

Drews, G. (1983). Mikrobiologisches Praktikum, p. 11. Berlin: Springer.

Ezaki, T., Hashimoto, Y. \& Yabuuchi, E. (1989). Fluorometric deoxyribonucleic acid-deoxyribonucleic acid hybridization in microdilution wells as an alternative to membrane filter hybridization in which radioisotopes are used to determine genetic relatedness among bacterial strains. Int J Syst Bacteriol 39, 224-229.

Jung, S.-Y., Kang, S.-J., Lee, M.-H., Lee, S.-Y., Oh, T.-K. \& Yoon, J.-H. (2005). Gaetbulibacter saemankumensis gen. nov., sp. nov., a novel member of the family Flavobacteriaceae isolated from a tidal flat sediment in Korea. Int J Syst Evol Microbiol 55, 1845-1849.

Jung, S.-Y., Oh, T.-K. \& Yoon, J.-H. (2006a). Colwellia aestuarii sp. nov., isolated from a tidal flat sediment in Korea. Int $J$ Syst Evol Microbiol 56, 33-37.

Jung, S.-Y., Kim, H.-S., Song, J. J., Lee, S.-G., Oh, T.-K. \& Yoon, J.-H. (2006b). Kribbia dieselivorans gen. nov., sp. nov., a novel member of the family Intrasporangiaceae. Int J Syst Evol Microbiol 56, 2427-2432.

Kim, I.-G., Lee, M.-H., Jung, S.-Y., Song, J. J., Oh, T.-K. \& Yoon, J.-H. (2005). Exiguobacterium aestuarii sp. nov. and Exiguobacterium marinum sp. nov., isolated from a tidal flat of the Yellow Sea in Korea. Int J Syst Evol Microbiol 55, 885-889.

Komagata, K. \& Suzuki, K. (1987). Lipids and cell-wall analysis in bacterial systematics. Methods Microbiol 19, 161-207.

Lanyi, B. (1987). Classical and rapid identification methods for medically important bacteria. Methods Microbiol 19, 1-67.

Lechevalier, M. P. \& Lechevalier, H. A. (1970). Chemical composition as a criterion in the classification of aerobic actinomycetes. Int $J$ Syst Bacteriol 20, 435-443. 
Leifson, E. (1963). Determination of carbohydrate metabolism of marine bacteria. J Bacteriol 85, 1183-1184.

Lim, J.-M., Jeon, C. O., Lee, J.-C., Song, S.-M., Kim, K.-Y. \& Kim, C.-J. (2006). Marinimicrobium koreense gen. nov., sp. nov. and Marinimicrobium agarilyticum sp. nov., novel moderately halotolerant bacteria isolated from tidal flat sediment in Korea. Int J Syst Evol Microbiol 56, 653-657.

Maszenan, A. M., Seviour, R. J., Patel, B. K. C., Schumann, P. \& Rees, G. N. (1999). Tessaracoccus bendigoensis gen. nov., sp. nov., a Gram-positive coccus occurring in regular packages or tetrads, isolated from activated sludge biomass. Int J Syst Bacteriol 49, $459-468$.

Nakamura, K., Hiraishi, A., Yoshimi, Y., Kawaharasaki, M., Masuda, K. \& Kamagata, Y. (1995). Microlunatus phosphovorus gen. nov., sp. nov., a new gram-positive polyphosphate-accumulating bacterium isolated from activated sludge. Int J Syst Bacteriol 45, 17-22.

Pitcher, D. G. \& Collins, M. D. (1991). Phylogenetic analysis of some LL-diaminopimelic acid-containing coryneform bacteria from human skin: description of Propionibacterium innocuum sp. nov. FEMS Microbiol Lett 84, 295-300.

Sasser, M. (1990). Identification of Bacteria by Gas Chromatography of Cellular Fatty Acids, Newark, DE: MIDI Inc.

Stackebrandt, E., Schumann, P., Schaal, K. P. \& Weiss, N. (2002). Propionimicrobium gen. nov., a new genus to accommodate Propionibacterium lymphophilum (Torrey 1916) Johnson and Cummins $1972,1057^{\mathrm{AL}}$ as Propionimicrobium lymphophilum comb. nov. Int J Syst Evol Microbiol 52, 1925-1927.

Tamaoka, J. \& Komagata, K. (1984). Determination of DNA base composition by reversed-phase high-performance liquid chromatography. FEMS Microbiol Lett 25, 125-128.
Tamura, T., Takeuchi, M. \& Yokota, A. (1994). Luteococcus japonicus gen. nov., sp. nov., a new gram-positive coccus with LL-diaminopimelic acid in the cell wall. Int J Syst Bacteriol 44, 348-356.

Wayne, L. G., Brenner, D. J., Colwell, R. R., Grimont, P. A. D., Kandler, O., Krichevsky, M. I., Moore, L. H., Moore, W. E. C., Murray, R. G. E. \& other authors (1987). International Committee on Systematic Bacteriology. Report of the ad hoc committee on reconciliation of approaches to bacterial systematics. Int J Syst Bacteriol 37, 463-464.

Yokota, A., Tamura, T., Takeuchi, M., Weiss, N. \& Stackebrandt, E. (1994). Transfer of Propionibacterium innocuum Pitcher and Collins 1991 to Propioniferax gen. nov. as Propioniferax innocua comb. nov. Int J Syst Bacteriol 44, 579-582.

Yoon, J.-H., Kim, H., Kim, S.-B., Kim, H.-J., Kim, W. Y., Lee, S. T., Goodfellow, M. \& Park, Y.-H. (1996). Identification of Saccharomonospora strains by the use of genomic DNA fragments and rRNA gene probes. Int J Syst Bacteriol 46, 502-505.

Yoon, J.-H., Lee, S. T. \& Park, Y.-H. (1998). Inter- and intraspecific phylogenetic analysis of the genus Nocardioides and related taxa based on 16S rRNA sequences. Int J Syst Bacteriol 48, 187-194.

Yoon, J.-H., Kang, K. H. \& Park, Y.-H. (2003). Psychrobacter jeotgali sp. nov., isolated from jeotgal, a traditional Korean fermented seafood. Int J Syst Evol Microbiol 53, 449-454.

Yoon, J.-H., Kang, K. H. \& Oh, T.-K. (2005). Erythrobacter luteolus sp. nov., isolated from a tidal flat of the Yellow Sea in Korea. Int J Syst Evol Microbiol 55, 1167-1170.

Yurkov, V., Stackebrandt, E., Holmes, A., Fuerst, J. A., Hugenholtz, P., Golecki, J., Gad'on, N., Gorlenko, V. M., Kompantseva, E. I. \& Drews, G. (1994). Phylogenetic positions of novel aerobic, bacteriochlorophyll $a$ containing bacteria and description of Roseococcus thiosulfatophilus gen. nov., sp. nov., Erythromicrobium ramosum gen. nov., sp. nov., and Erythrobacter litoralis sp. nov. Int J Syst Bacteriol 44, 427-434. 